\author{
A.A. Tasbulatova ${ }^{1} \mathbb{D}$, E.B. Zhatkanbayev ${ }^{1}(\mathbb{D}$, \\ S.K. Atakhanova ${ }^{1} \mathbb{D}$, Zhao Haifeng ${ }^{2}$ (D) \\ 'Al-Farabi Kazakh national university, Kazakhstan, Almaty, \\ e-mail: Aliya.Tasbulatova@kaznu.kz, zhatkanbayev.yerzhan@kaznu.kz, atakhanova.saltanat@kaznu.kz \\ ${ }^{2}$ Harbin University of Technology, China, Heilongjiang prov., Harbin, \\ e-mail: Zhaohaifeng_c@yahoo.com.cn
}

\title{
ANALYSIS OF FINLAND'S EXPERIENCE IN INVOLVING YOUNG PEOPLE IN POLITICAL ISSUES
}

Kazakhstan is a country that has committed itself to implementing the norms of the Convention on the Rights of the Child. Today, a large number of measures are being taken to protect the rights of children and ensure the rights of young people. However, according to the author and other researchers, many issues have not been properly fixed in the legislation of Kazakhstan and, accordingly, have not been implemented properly. According to the author, it is in the issues of involving young people in the political life of the country that Kazakhstan should make a big step forward. Analysis of the current state of youth policy shows that it is mainly aimed at solving social problems of young people. However, the current state of Affairs, and above all in the interests of the state, requires active involvement of young people in solving regional and national issues. In this regard, the authors believe that it is necessary to use the experience of countries that are most advanced in the study area. Finland is a country that has laid the foundations for a permanent dialogue between the state and youth. The article provides a fairly detailed analysis of the created mechanism of interaction between society, the state and an individual. The study was conducted through an analysis of Finnish legislation, which obliges educational institutions, municipalities and public authorities to take into account the views of children and young people when making decisions. A study of the built mechanism of interaction, which covers all stages of children's growth and youth's maturation, was conducted. This experience can be used to improve the youth policy of Kazakhstan, which requires serious improvement.

Key words: children, youth, children's rights, political rights of children, youth policy.

А.А. Тасбулатова' ${ }^{1}$ Е.Б. Жатканбаев ${ }^{1}$, С.К. Атаханова ${ }^{1}$, Чжао Хайфенг ${ }^{2}$

'Ә^-Фараби атындағы Қазақ ұлттық университеті, Қазақстан, Алматы қ., e-mail: Aliya.Tasbulatova@kaznu.kz, zhatkanbayev.yerzhan@kaznu.kz, atakhanova.saltanat@kaznu.kz ${ }^{2}$ Харбин технологиямық, университеті, Қытай, Хэйлунцзян провинциясы, Харбин қ., e-mail: Zhaohaifeng_c@yahoo.com.cn

\section{ФинАяндияның жастарды саяси мәселелерге тарту тәжірибесін талдау}

Қазақстан - алам құқықтарын қорғау туралы конвенцияның ережелерін орындауға міндеттенген мемлекет. Бүгінгі таңда балалардың құқықтарын қорғау және жастардың құқығын қамтамасыз ету бойынша үлкен шаралар кешені қабылдануда. Сонымен бірге, автордың және басқа зерттеушілердің пікірі бойынша көптеген мәселелер Қазақстан заңнамасында тиісті түрде бекітілмеген және тиісінше, тиісті деңгейде орындалмаған. Автордың пікірінше, жастарды елдің саяси өміріне тарту мәселелерінде Қазақстан алға үлкен қалам жасауы керек. Жастар саясатының қазіргі жағдайын талдау, оның барлығы негізінен жастардың әлеуметтік мәселелерін шешуге бағытталғандығын көрсетеді. Алайда, қазіргі жағдай, ең алдымен, мемлекет мүдлесі үшін аймақтық және ұлттық мәселелерді шешуге жастардың белсенді қатысуы қажет. Осыған байланысты авторлар зерттелген бағытта алдыңғы қатарлы елдердің тәжірибесін пайдалану қажет деп санайды. Финляндия - бұл мемлекет пен жастар арасындағы тұрақты диалогтың негізін салған ел. Мақалада қоғам, мемлекет және жеке тұлға арасындағы өзара іс-қимылдың қалыптасқан тетігіне жеткілікті түрде егжейтегжейлі талдау берілген. Зерттеу білім беру ұйымдарын, муниципалитеттер мен мемлекеттік органдарды шешім қабылдауда балалар мен жастардың көзқарастарын қабылдауға және ескеруге міндеттейтін Финляндия заңнамасын талдау арқылы жүргізілді. Орнатылған өзара әрекеттесу механизмі зерттелді, ол балалардың өсуі мен жастық шақтың барлық кезеңдерін 
қамтиды. Бұл тәжірибені байыпты қайта қарауды қажет ететін Қазақстанның жастар саясатын жетілдіру үшін пайдалануға болады.

Түйін сөздер: балаяар, жастар, балалардың құқығы, балалардың саяси құқығы, жастар саясаты.

\author{
А.А. Тасбулатова ${ }^{1}$, Е.Б. Жатканбаев ${ }^{1}$, Атаханова С.К. ${ }^{1}$, Чжао Хайфенг ${ }^{2}$ \\ ${ }^{1}$ Казахский национальный университет имени аль-Фараби, Казахстан, г. Алматы, \\ e-mail: Aliya.Tasbulatova@kaznu.kz, zhatkanbayev.yerzhan@kaznu.kz, atakhanova.saltanat@kaznu.kz \\ ${ }^{2}$ Харбинский технологический университет, Китай, провинция Хэйлунцзян, г. Харбин, \\ e-mail: Zhaohaifeng c@yahoo.com.cn
}

\title{
Анализ опыта Финяяндии по вовлечению молодежи в помитические вопросы
}

\begin{abstract}
Казахстан является страной, которая взяла на себя обязательства по реализации норм Конвенции по защите прав человека. Сегодня проводится большой комплекс мероприятий по защите прав детей и обеспечению прав молодежи. Вместе с тем, по мнению автора и иных исследователей, многиевопросынеполучилидолжной закрепления в законодательствеКазахстана и соответственно не реализованы должным образом. По мнению автора, именно в вопросах вовлечения молодежи в политическую жизнь страны Казахстану следует слелать большой шаг вперед. Анализ современного состояния молодежной политики показывает, что вся она, главным образом, направлена на решение социальных проблем молодежи. ОАнако, современное состояние дел, и прежде всего, в интересах государства, требует активно привлекать молодежь в решение вопросов регионального и национального уровня. В этой связи, авторы считают, что необходимо использовать опыт стран, наиболее продвинутых в исследуемом направлении. Фин^яндия является страной, заложившей основы постоянного Аиалога государства и молодежи. В статье проводится Аостаточно подробный анализ созданного механизма взаимодействия общества, государства и отдельно взятой мичности. Исследование проведено посредством анализа законодательства Финляндии, которое обязывает образовательные учреждения, муниципа^итеты и государственные органы воспринимать и учитывать мнения детей и молодежи при принятии решений. Проведено исследование выстроенного механизма взаимодействия, который охватывает все стадии роста детей и взросления молодежи. Аанный опыт может быть использован Аля совершенствования молодежной политики Казахстана, которая требует серьезной доработки.
\end{abstract}

Ключевые слова: дети, молодежь, права детей, политические права детей, молодежная политика.

\section{Introduction}

In the Message to the people of Kazakhstan of the Head of state "Constructive public dialogue the basis of stability and prosperity of Kazakhstan" dated September 2, 2019 Kasym-Jomart Tokayev defines further directions for the development of a modern effective state, including by establishing a "permanent dialogue between the government and society, you can build a harmonious state, embedded in the context of modern geopolitics. Therefore, it is necessary to support and strengthen civil society, to involve it in the discussion of the most urgent national problems in order to solve them" (https://www.akorda.kz/ru/addresses/addresses_ of_president/poslanie-glavy-gosudarstva-kasymzhomarta-tokaeva-narodu-kazahstana).

This position of the President is supported by his further intentions: "my political priority is to attract young people to power, to help solve issues of national importance. Representatives of protest movements will be invited to the round table, and issues will be resolved in this way, not in the streets, in an atmosphere of unrest and chaos", the Head of state said in an interview with Euronews.

This statement of the President of the Republic of Kazakhstan is associated with a serious activation of the population in the spring-summer of 2019. The government is forced to engage in a dialogue with the population of the country to identify and solve urgent problems. The head of state instructed to develop and adopt the Concept of civil society development until 2025. Young people represent a certain part of the population (1/3) and their involvement in solving vital issues is a strategic task of any modern state (https://www.kazpravda. $\mathrm{kz} /$ news/prezident2/moi-prioritet--privlecheniemolodezhi-k-resheniu-voprosov-gosudarstvennoivazhnosti--tokaev-v-intervu-euronews).

At the same time, our countries, including Kazakhstan, are interested in and need to analyze the experience of EU countries that have invaluable 
experience in involving young people in political decision-making to develop political strategies and structures to promote youth participation.

It should be noted that the problem of youth participation in the resolution of public interests began to rise in the early twentieth century, but the greatest emphasis was made in the early twentyfirst century. In its 2008 report, UNICEF notes that "participation has been described as a fundamental prerogative in the Convention on the Rights of the Child, but language regarding the right to participate is quite rare in defining special conditions for children in different countries" "considers participation as an opportunity for young people to speak out and help resolve issues, planning and decisionmaking processes that directly affect children and young people, and for which they are able to make decisions" (Feldmann-Wojtachnia 2011). In this regard, international organizations have come to the conclusion that a policy of engagement is necessary. And if we are only at the stage of securing and ensuring the participation of young people in public life, the countries of Western Europe have long moved to the policy of involvement.

\section{Main part}

International organizations have developed a certain approach to involving the public in the system of public administration. This is due to the fact that young people are recognized as a separate social group that needs comprehensive support during the transition period of independence; this also applies to psychological and social aspects, as well as the involvement of young people in political processes. To this end, the EU and the Council of Europe have adopted a number of documents related to youth. The Council of Europe's activities in the field of youth rights are based on the action plan "Building cohesive societies" and the agenda for 2020, which is the basis of the Council of Europe's youth policy.

It is always based on the "Arnstein citizen participation ladder" (Arnstein, 1969), which consists of 8 stages, where civil control, delegation of authority, and partnership are at the top, which are segments of public involvement in public administration.

The EU has developed a policy of General participation in decision-making, which consists of five components: information, consultation, involvement, cooperation and empowerment (http:// www.iap2.org.au/resources/iap2s-publicparticipation-spectrum2013).
However, the basis of the youth engagement policy is the "Arnstein ladder", which was adapted by Roger HART and also includes 8 steps, of which 5 represent real participation, and the last 3 are nominal, i.e. symbolism, decorative role and manipulation. Those we are interested in include:

"Step 8: Joint decision-making - Projects or ideas are put forward by young people who invite adults to participate in the decision-making process as partners.

Step 7: youth-led and youth-initiated Projects or ideas are put forward by young people and led by young people; adults may be asked to provide the necessary support, but the project can be implemented without their intervention.

Step 6: Initiated by adults, joint decisions with young people-Projects are put forward by adults, but young people are invited to participate in decisionmaking and responsibility as equal partners.

Step 5: young people are consulted and informed-Projects are put forward by adults and adults lead them, while young people put forward their ideas and suggestions and are informed about how these suggestions are taken into account in final decisions or in final results.

Step 4: Young people are given a task, but are informed - Projects are put forward by adults and implemented by them; young people are invited to play a role or perform a task in the project, but they understand their real influence" (Hart, 1992).

These five components are used to build a policy of engagement and, accordingly, a policy of youth participation in decision-making in the EU, which, according to the UN, is the most advanced in this area. It should be noted that the EU has a common policy, including with regard to young people, in order to further integrate them. According to E.N. Grachev: "the EU Youth policy can be understood as a "soft power" in the case of interstate integration within the European Union. As a communicative tool, it is designed to create favorable conditions for the formation of a single, from the point of view of values, European youth, which would no longer perceive itself at the level of a particular nation, but is precisely European" (Grapev, 2019: 79).

The EU's youth policy is based on a number of programs, which are based on the first program "Youth for Europe". All these programs are based on a number of documents: the White paper "New incentives for Europe's youth" (2001), the European youth Pact (2005), the European Commission Communique "Support for the full participation of young people in education employment and society" 
(2007), the youth policy Strategy "Youth-investing and providing opportunities" for the period 20102018, which "became a kind of stage in the process of forming a pan-European youth policy" (Grapev 2019: 79).

It should be noted that, despite the promotion of a single EU youth policy, each country develops and implements its own policy within the European framework. However, "there is no generally accepted definition of youth policy or what it includes. Each country has its own national policy and decides what youth policy should include" (Ashing, 2010).

In turn, of the 28 countries, two countries have the most effective experience - Finland and the Federal Republic of Germany, which work closely together on these issues and have achieved significant results. Their experience can be called phenomenal.

The experience of Finland is widely studied by modern scientists as a phenomenon of children's participation.

It should be noted that the legislative process of youth involvement in decision-making was laid down in Finnish legislation in the 70s of the last century by the adoption of the Law on State transfers for national youth work $(1035 / 1973)$ entered into force in 1974, creating a "support System that has already been applied on the basis of allocations allocated from the state budget every year" [9, p. 120]. Whereas N. Helve, emphasizes that the processes themselves began long before this and cites as an example the work of the nuorisoseuraliike youth Association, which was founded in Finland in 1897 for the purpose of educating rural youth. And in 1963, the United Nations Committee of students (Ylioppilaiden YK-yhdistys) was created, which provided opportunities for young people to promote foreign policy debates (Helve, 2009).

The level of democracy in Finland is very high, which is ensured primarily by the current legislation, which thoroughly prescribes the procedural aspects of all administrative procedures. Regarding our topic, it is constitutionally stipulated that "public authorities are obliged to create conditions for the participation of persons living in the country in public activities and their influence on decisions affecting them" (http://www.finlex.fi/fi/laki/ kaannokset/1999/ru19990731.pdf). This provision for young people is enshrined in the youth Act (72/2006). One of the main goals of this Law is to "promote the social inclusion of young people and provide them with opportunities to influence and improve their skills and ability to function in society" (https://www.abo.fi/wp-content/uploads/2019/06/
Riekkinen-et-al_-Promoting-the-Social-Inclusionof-Youth_2019.pdf).

In addition, it stipulates that "the opportunity to participate in the consideration of issues related to local and regional youth work and policy should be given to young people. Additionally, young people should be heard when addressing issues that concern them." Another important source of participation is the incorporation of articles 20 and 21 of the Finnish child protection Act, which are specifically dedicated to elucidating and hearing the child's opinion and using the child's right to speak, which must be taken into account in relation to their age and level of development in matters related to their child protection cases (https://www.finlex.fi/fi/laki/ kaannokset/2007/ru20070417 20131292.pdf).

In addition to the Declaration, Finnish legislation sets strict procedures and requirements for all institutions that work directly with children and young people. Thus, the Basic law on education establishes the obligation for all educational institutions "providing secondary and vocational education and training, to have a school Board consisting of students of this institution", which is controlled by the Ombudsman for children. If such an Association is not created, the Directorate is obliged to take other measures to ensure that students can Express their opinion on the collective interests of students, which ensures the influence of students on the programs and activities of educational institutions (https://www.abo.fi/wp-content/uploads/2019/06/ Riekkinen-et-al_-Promoting-the-Social-Inclusionof-Youth_2019.pdf).

It should be especially noted that the state has systematically approached the issue of children's participation since 2006 by implementing a certain policy through a number of national children's youth participation projects " participating student community school" whose purpose was "to promote the active development among the students a sense of community, of belonging and improvement in schools" (Timofeev 2016) in addition, the school with grade 9, a course of Civil law, which is in contrast to our classical understanding of the subject, is taught with the aim of "educating active and responsible citizens who are familiar with the basic social structures and able to participate actively in society" [Youth participation in Finland and Germany]. In a number of schools, students have the opportunity to participate directly in the preparation of curricula and the use of teaching methods. However, in most schools in Finland, school demonstrations were held, as students felt that their opinions were not heard (from 18 to $33 \%$ of students), they protested 
that they were not heard in the decision-making process and therefore did not take proper part in making important issues for their education. This has led to major changes in the education system of Finland, which is considered one of the countries in the best school system in the world (9th place in the ranking of Pearson: Global Index of Cognitive Skills and Educational Acquisition 2016 (https://gtmarket. $\mathrm{ru} /$ ratings/global-index-of-cognitive-skills-andeducational attainment/info).

The Finnish legislator's approach to the age of the right to Association and the right to demonstrate is interesting. Neither the Constitution nor special regulations set a minimum age limit for the exercise of these rights. For example, section 7 of the Finnish Association Act 1989 / Yhdistyslaki $(503 / 1989) 22$ requires that the founder of the Association must be 15 years old. This is according to M. Litmala means that "members of the Association may be under 15 years of age if they meet the requirements set for members of the Association and the corresponding Association accepts their membership (M. Litmala \& Mirva Lohiniva-Kerkelä, 2005: 33-34). In addition, the Finnish Political parties / Puoluelaki Act of 1969 $(10 / 1969)$ stipulates that a party must have at least 5,000 "eligible" voters in parliamentary, municipal or European Parliament elections. This, according to M. Riekkenen, suggests that "those who do not have the right because they have not yet reached maturity can acquire membership in the party. This issue is resolved by the constituent documents of a particular party. In Finland, youth units have been set up under this aegis to prepare young generations to become party members after reaching maturity." (https://www.abo.fi/en/institute-for-human-rights/)

The same picture applies to the right to demonstrate, which is considered very important for Finnish youth. For example, Section 5 of the Assembly Act 1999 Finland / Kokoontumislaki $(530 / 1999)$ sets a minimum age limit of 15 years only for organizers of public meetings, due to the special responsibilities of the organizers, taking into account organizational security (https://www.finlex.fi/fi/ laki/ajantasa/1999/19990530?search\%5Btype\%5 $\mathrm{D}=$ pika\&search\%5Bpika\%5D=Kokoontumislaki). This essentially creates an opportunity for younger people to legally participate in peaceful rallies and demonstrations without fear of persecution and punishment, as is done, for example, in Russia and Kazakhstan.

In our opinion, special attention should be paid to a certain system of state and public institutions whose activities are aimed at supporting youth initiatives. This system is actually determined by the existing experience of this country and is enshrined in the Finnish youth Law, which is adopted every decade, which is justified by serious changes in this issue.

Thus, the Nuorisolaki youth Act of 2006 $(1285 / 2016)$ and the Government Decree no. 2011/2017 adopted for its implementation establishes the following system:

1. The Ministry of education and culture, which is responsible for the overall coordination of issues in the field of national youth policy and the creation of appropriate conditions for its implementation;

2. The state Council for youth Affairs, which operates under the auspices of the Ministry and its goal is " to present initiatives and proposals for the development of youth policy; generate upto-date information about young people and their living conditions; issue applications to the Ministry of Education and culture on issues that should be considered in the national youth work and policy program and monitor international events and cooperation in this area (https://www.finlex.fi/fi/ laki/ajantasa/2016/20161285? search\%5Btype\%5D $=$ pika\&search $\% 5$ Bpika $\% 5 \mathrm{D}=$ Nuorisolaki $)$.

3. The national organisation for youth work, whose activities are aimed at realization of the governmental programs for youth. The Political program for 2017-2019 was adopted on October 12,2017 , "national youth work and youth", which identified 5 strategic goals, one of which is "more opportunities for participation and influence of individuals will be created" [19].

4. Municipalities (26), which are charged with the responsibility of conducting "the actual implementation of youth work and policies and creating the necessary prerequisites for local youth work and activities, providing services and facilities for young people and supporting their civic engagement"(https://minedu.fi/ documents/1410845/4276311/Government+Decree + on+youth+work+and+policy+2017).

5. Youth Councils are formed in municipalities. According to the Finnish law on local government / Kuntalaki (410/2015), "they should be given the opportunity to influence the planning, preparation, implementation and monitoring of the activities of the various areas of responsibility of the municipality in terms of welfare, health, education, living conditions, housing for the residents of the municipality, as well as other issues that the youth Council considers important for children and young people. Youth councils should participate in the municipality's efforts to promote the participation of 
children and young people, as well as the opportunity to Express their opinions" (https://www.finlex.fi/fi/ laki/ajantasa/2015/20150410?search\%5Btype\%5D $=$ pika\&search $\% 5$ Bpika $\% 5 \mathrm{D}=$ kuntalaki).

6. School board;

7. Youth expertise centers are an important link in this system, as they are responsible for evaluating and analyzing youth organizations. Their goal is "to support the implementation of the goals set out in the national youth work and policy program by developing and promoting competence, experience and communication in the youth sector". In fact, according to their submission, the Ministry of education and culture finances the activities of youth organizations.

\section{Conclusion}

A scientific study conducted by M. Riekkenen on the issue of youth activity in Finland shows the richness of the choice of youth organizations in this small country. This includes Finnish alliances, consortia, associations, Finnish youth research societies, etc., some of which are funded directly by the Ministry, and the rest by territorial units.

Thus, according to Finnish researchers, "Finnish legislation establishes a legal framework, as well as specific mechanisms for youth empowerment, ensuring effective social inclusion of the latter. Mechanisms for youth participation and inclusion supported by government agencies are diverse, ranging from guarantees of participation rights to the right to be heard and the right to receive assistance in the labor market to more detailed ways of influencing, such as youth barometers and youth discussion forums. What is important in Finland with regard to youth participation and youth work is a "tripod structure", with the participation of the Ministry of education and culture, youth expert centers and the youth research network. This structure makes it possible to effectively promote the rights of young people, using the skills, knowledge and experience of different partners" (Helve, 2009: 120).

\section{References}

Ashing I. Youth and youth policy -a Swedish perspective / / Introduction to Youth Policy -Swedish and Turkish Perspectives. 2010.

Constitution of Finland of 11 June 1999 // http://www.finlex.fi/fi/laki/kaannokset/1999/ru19990731.pdf

Grapev E. N. Youth policy in the European Union: national and supranational levels. Diss. On the job. academic step. Ph. D., 2019, P. 223

International Association for Public Participation, Public Participation Spectrum, IAP2, 2013. http:// www.iap2.org.au/resources/iap2s-public-participation-spectrum2013

Finland, Government Decree on Youth Work and Policy 211/2017, the unofficial translation of this Decree is reproduced at the web page of the Finnish Ministry of Education and Culture and is available at: https://minedu.fi/documents/1410845/4276311/Gove rnment+Decree+on+youth+work+and+policy +2017

H. Helve, 'the Finnish Perspective: Youth Work, Policy and Research', in: Griet Veschelden et al (eds), The History of Youth Work in Europe: Relevance for Youth Policy Today, Strasbourg: Council of Europe Publishing, 2009 pp. 117-129.

Message of the Head of state K. K. Tokayev to the people of Kazakhstan "Constructive public dialogue-the basis of stability and prosperity of Kazakhstan” dated September 2, 2019 // https://www.akorda.kz/ru/addresses/addresses_of_president/poslanie-glavygosudarstva-kasym-zhomarta-tokaeva-narodu-kazahstana

M. Litmala \& Mirva Lohiniva-Kerkelä (toim.), Nuoren oikeudet, Helsinki: Edita, 2005 at 33-34

My priority is to involve young people in solving issues of national importance. K. Tokaev in an interview with Euronews // https://www.kazpravda.kz/news/prezident2/moi-prioritet--privlechenie-molodezhi-k-resheniu-voprosov-gosudarstvennoi-vazhnosti--tokaev-v-intervu-euronews

Roger Hart, (1992) "Child Participation: from symbolism to citizenship", UNICEF Innocenti Research center, Florence.

Sherry R. Arnstein, “a Ladder of Citizen Participation,” Journal of the American Planning Association, 35, no. 4 (1969): 216 224.

The Finnish youth act 2016 / Nuorisolaki (1285/2016), available at: https://www.finlex.fi/fi/laki/ajantasa/2016/20161285?searc $\mathrm{h} \% 5 \mathrm{Btype} \% 5 \mathrm{D}=$ pika\&search $\% 5 \mathrm{Bpika} \% 5 \mathrm{D}=$

The law on the protection of children 13.4.2007/417 // https://www.finlex.fi/fi/laki/kaannokset/2007/ru20070417_20131292.pdf

The 2018 High-School Act of Finland/Lukiolaki (714/2018), available at: https:/www.finlex.fi/fi/laki/ajantasa/2018/20180714 ?search $\% 5$ Btype $\% 5 \mathrm{D}=$ pika\&search $\% 5$ Bpika $\% 5 \mathrm{D}=$ Lukiolaki

Timofeev F. V. Effective investments in skills of the XXI century. Preliminary comparative analysis of the experience of Russia and Finland / / SNK-Petersburg. 2016 P. 40. 
Promoting the social inclusion of youth and access to labor markets: experiences in Finland, Sweden, and Russia / Mariya Riekkinen, Liya Kalinnikova Magnusson, Natalia Miuller, George Varlamov, Alexey Antipov, Kristina Kirillova, Mariya Prokopchik, Iulia Gorokhova. - Turku / Åbo : Åbo Akademi University, Institute for Human Rights, 2019 // https://www.abo.fi/en/institute-forhuman-rights/

The 1999 Assembly Act of Finland/Kokoontumislaki (530/1999), available at: https://www.finlex.fi/fi/laki/ajantasa/1999/1999 0530?search\%5Btype \%5D=pika\&search\%5Bpika\%5D=Kokoontumislaki

The 2016 Youth Act of Finland/Nuorisolaki (1285/2016), available at: https://www.finlex.fi/fi/laki/ajantasa/2016/20161285?se $\operatorname{arch} \% 5 \mathrm{Btype} \% 5 \mathrm{D}=$ pika\&search $\% 5 \mathrm{Bpika} \% 5 \mathrm{D}=$ Nuorisolaki

The 2015 Local Government Act of Finland/Kuntalaki (410/2015), available at: https://www.finlex.fi/fi/laki/ajantasa/2015/201 50410 ?search $\% 5$ Btype $\% 5 \mathrm{D}=$ pika\&search $\% 5 \mathrm{Bpika} \% 5 \mathrm{D}=$ kuntalaki.

Youth participation in Finland and Germany. Analysis of the issue status and recommendations based on the received data / / Eva Feldmann-Wojtachnia, Anu Gretschel, Vappu Helmisaari, Tomi Kiilakoski, Aila-Leena Matthies, Sigrid Meinhold-Henschel, Roland Roth, Pia Tasanko. Youth research network of Finland. Helsinki, Finland 2011. $100 \mathrm{c}$. 